\title{
Transatlantica
}

Revue d'études américaines. American Studies Journal

\section{The Values of Cultural Exchange}

\section{Derrick Cartwright}

\section{(2) OpenEdition}

Journals

Édition électronique

URL : http://journals.openedition.org/transatlantica/331

DOI : 10.4000/transatlantica.331

ISSN : 1765-2766

Éditeur

AFEA

\section{Référence électronique}

Derrick Cartwright, «The Values of Cultural Exchange », Transatlantica [En ligne], 1 | 2001, mis en ligne le 23 mars 2006, consulté le 29 avril 2021. URL : http://journals.openedition.org/transatlantica/331 ; DOI : https://doi.org/10.4000/transatlantica.331

Ce document a été généré automatiquement le 29 avril 2021.

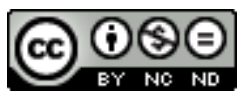

Transatlantica - Revue d'études américaines est mis à disposition selon les termes de la licence Creative Commons Attribution - Pas d'Utilisation Commerciale - Pas de Modification 4.0 International. 


\title{
The Values of Cultural Exchange
}

\author{
Derrick Cartwright
}

1 This dialogue, convoked today around the idea of "America, The Image" permits me to think aloud about several themes of special interest to the Musée d'Art Américain à Giverny at this moment: what we do, why we do it, and how we might do it better? Most of all, I am grateful for the chance to explore the role(s) that can be played by an American art institution in France. Because we are rather unique in this regard, a certain responsibility for the "image of American art" adheres to this exploration. Without even special flag-waving, what this musée does with its images, all of them American, has a precise political value and a precise currency. We represent American culture to Europeans, many of whom-let's be honest-find (or profess to find) the idea of American "culture" oximoronic. ${ }^{1}$

2 A museum is a space of exchanges, some aesthetic, some economic, certainly some social. This will be a talk, then, about the value of cultural exchanges, but also in a more limited sense about exchange values in Giverny, both historically and at the present time. I would like first to point to some of the advantages (as well as perhaps some of the disadvantages) of the specific location and identity of a museum in Giverny at the beginning of the $21^{\text {st }}$ century. To begin, however, we should think a little about how such things come into being.

3 Permit me to sketch the barest of narrative backgrounds for my principal objective, which is to better locate for the participants in this conference the Musée d'Art Américain à Giverny within a broader network of cultural institutions, most especially those in Paris (which lies about 45 minutes to the west). The history of the village of Giverny is itself a history of cultural give-and-take. Although firm evidence of the circumstances surrounding the commune's founding does not exist, the place had early and distinct associations as a leper colony (something a little different than its subsequent reputation as an famous artist's colony, to be sure). A Norman hamlet developed here, afterward, perhaps as a result of the fact that an outpost of the monastic community in Rouen was established here in Medieval times.

4 The fertile southern-exposed slopes of our hillsides were excellent for the Rouennais monks' apple orchards, and thus Giverny became a cider-making base for that 
ecclesiastical center to our northwest. In fact, a quick inspection of the basic cultural geography of the village clearly reveals this original orientation, with the church of Ste Radegonde (a Saint associated with leprosy, if I am not mistaken), terraced slopes behind, and a number of associated structures all placed at the end of the village closest to this destination. None of this took place very far from the established water and roadways that would-still do-connect Giverny and Rouen. After the French Revolution the monastic base dispersed/disappeared, and the economic vitality of the village withered. The village waited for Claude Monet to move within its limits, which he did in the summer of 1883 , before it developed a new identity for itself toward the Paris (which is to say, West)-oriented end of the village, this time as an artist's colony.

In fact, we know that most inhabitants of the village were commercially (if not socially) unprepared for the waves of young American artists who rolled in after word of Monet's presence spread through their ranks. Considering its primarily agrarian setting-with no established guest lodgings, just a few small cafés, a single grocer, and surely no ready source of artists materials-we must admit that the place was, in fact, spectacularly ill-suited to becoming an attractive cultural retreat. However, that is certainly one of the reasons why Monet came in the first place. That is to say, he chose it because it lacked many of the surroundings that he had previously found in Argenteuil, Vetheuil, and Poissy where he lived prior to moving to Giverny. The promise of a cheap, unfettered life in the country surely played a role in his selection of the property he began by renting (and ultimately bought in 1890) from M. Singeot. Enterprising locals took advantage (in all senses of the term) of the basic absence of hotels and materials, to say nothing of their physical distance from competitors, to create lucrative side-businesses for themselves. The Hotel Baudy example is perhaps the most legendary in this regard. The Baudy family ran the general store, which ultimately became a fine hostelry. They later built skylit studio spaces, sometimes to accommodate a single artist's request (I am told this was the precisely the case with Paul Cezanne's extended stay in Giverny in 1894) and ultimately became high-end art suppliers for this itinerant community. Tennis courts were added around the turn of the century to complete the resort lifestyle.

6 The First World War brought an unwelcome end to most expatriate activity here and Monet's death on Dec. $5^{\text {th }} 1926$ surely clinched that fact. Yet, the legendary impressionist inspired subsequent artists to explore this region. I recently learned (through some of the artist's own descendants, incidentally) that a group of surrealist writers and artists came to Giverny in the late 1920s and 30s, and so surely the creative reputation of the place lingered on for some time. Still, the demise of the largely American-based art colony in Giverny marked an end to a commercially successful moment in its long history. The regeneration of the village in the 1970s and 1980s, first accomplished by the renovations of the Fondation Monet, and then continued by the Terra Foundation for the Arts in the 1990s, marks a renewal of the cultural investment in this historically significant region.

7 The Musée d'Art Américain first opened to the public in 1992. The institution was the visionary dream of Daniel J. Terra, who had already created a private museum in Chicago (Terra Museum of American Art) about a decade earlier. Across a period of approximately 25 years, Terra amassed a collection of almost 1000 objects, a significant percentage of them created in France. Together with several competing collectors, he is virtually responsible for creating the strong market for turn-of-the-century American 
artwork that still dominates auction sales in the U.S. It is possible to assign a variety of explanations to his museum-building impulses, of course. Still, it has to be admitted that one of the most pressing reasons was that he needed a place to house his growing inventory of images. Building an American art museum in the heart of one of America's largest cities is one thing, but when an American businessman, commits himself to building an "American" museum in rural France, he must have known that he was leaving himself open to accusations of eccentricity. Although Terra himself only ever acquired a bit of spoken French before his death in 1996, he was passionate in his efforts to communicate the value of American pictorial contributions-L'Amérique, Image tout court, if you will-to others, especially Europeans, maybe most especially the French public. For this man "transatlantic exchange" was the key to both American art's past and future. Put in the most guileless terms, he wanted to expose French audiences to American art's historic basis in Giverny, and through that inspire a new round of cultural collaborations. The American artists who worked in rural France at the turn-of-the-last-century represented incontrovertible proof of important cultural work, that for Mr. Terra personally (a first-generation Italian immigrant, and proverbial self-made man) had enormous consequence and value. Today, it is possible to suggest that the Musée d'Art Américain à Giverny stands as the most tangible evidence of Mr. Terra's ambition to revive a cultural presence for American art in a layered, indeed complex, terrain. We should ask, however: Is this a good thing?

8 A moment ago, I clumsily referred to Mr. Terra's ambition here as something "eccentric." I want to go back to my choice of that term, not to correct it, but to underline its positive valence. Eccentricity has some disadvantages, to be sure, but I also have to believe that it has certain virtues for purposes of cultural work. There is something undeniably eccentric about creating an internationally-aimed museum in a fundamentally small, provincial setting. Just as the distance that separates this place from the Parisian center can be seen as an incalculable factor of its eccentricity, the basic smallness of the place also plays a role in this equation. In Monet's day, the population of the village amounted to about 300 residents, and although it has grown slightly (my family and I have added 4 to that number at least), the place remains a tiny locale, too small even to appear on many standard roadmaps. Paradoxically, this small place currently attracts close to a million visitors every year. I've often been told that Giverny is the second largest tourist destination outside of Paris (after Versailles). While this status as penultimate attraction has a dubious side, I think it also points at perhaps a great advantage of the place: that is, it permits us to be "outside of Paris" yet certainly also permits us to be noteworthy enough to attract other "outsiders."

9 To be deliberately outside of Paris, after all, is what brought Monet to the villages downstream from the urban metropolis on the Seine that he also knew so well. The nearby countryside was the most quintessentially impressionist destination imaginable, after all. To be outside of Paris then, as today, meant to be "eccentric" in the sense of being apart from a center, the center. Eccentricity, in this sense, implies a certain liberty from the oversight and expectations of the cultural elite. For creative people, artists (or scholars), it means that they can risk mistakes without awful consequences. Surveillance is hardest to accomplish at the periphery, and outside of controlling institutional views, the eccentric subject can do as $\mathrm{s} /$ he pleases often with random and startling success. This is all proven by physics, where a centrifugal force 
wants forms to scatter wildly and without logical consequence. Sometimes this scattering hits an interesting target or brings other unexpected rewards.

Historically speaking, being eccentric meant that the artists who worked in Giverny, for example, Frederick Carl Frieseke, could paint nudes in the sunshine, something they might not dare in another context-Frieseke did not dare it in his native context of Michigan, for example (he told us this much in letters). It meant that a former monastery could be turned into an almost libertine party zone, which was the case with the MacMonnies family's occupation of le Moutier here. Today it means that we can experiment with programs that are at once ambitious, and auto-critical, without too much worry about submitting such enterprises to the institutional scrutiny of others. This is perhaps the most extreme value of all eccentric moves, it seems to me: the ability to be uninhibited.

11 I want now to turn, but briefly, to acknowledge what I consider to be the greatest dangers associated with what I would otherwise claim as the glorious status of "eccentricity": that is the danger of misunderstanding. Some of you already may have misunderstood me about several statements I have made. I take that for granted, for reasons I will turn to next. But ultimately, in order to be judged consequential and productive, even the most serenely eccentric place must communicate with a center, or preferably, centers. Monet surely knew this as he sent his works off dutily to Durand-Ruel, equally surely, and we must be cognizant of it too. Foreign cultural institutions operating in world capitals such as Paris are ubiquitous, of course, and their own inherent eccentricity is masked somewhat by the cosmopolitan nature of their placement in those centers. There is, however, something truly suspicious (I could say doubly eccentric) about a foreign cultural institution operating in an outsider's space. This can lead to apprehension and, certainly too, to misapprehensions. I am reminded of the fact that the Musée d'Art Américain à Giverny was originally called the Musée Americain Giverny; the "Art" part was added later because it was felt too many people were confused as to whether or not it was a memorial museum for the Normandy Beaches, which are located about 2 hours away.

Let me explain further what I am really concerned about. Everything we do here requires translation. The exhibitions, their catalogues, programs like the one we are involved in today, the dialogues with each other afterwards, all of these exchanges are inherently mediated, which is to say culturally contingent, acts. There is tremendous room for error in such acts. I recognize this because I am myself admittedly an exceptionally poor translator of French. When I say this I mean not just the language, but also the basic cultural habits and norms. As the staff I am privileged to work with will delight in telling you, I am sure, my efforts to translate directly what I mean into what they will understand as French are utterly bewildering at moments. I'll say more about this in a moment

In the end, I think this can not be much different that what was experienced by leading artists, such as Lila Cabot Perry, during the hey-day (how would you translate that word) of the American artist colony. Scholars have written authoritatively about Perry's life in Giverny. They have relied extensively on her own account, published in English in 1927, of her many dialogues with Monet. Evidently, Perry wrote down every word that the "world's greatest landscape artist" said to her during the 10-odd summers that she spent as his next-door neighbor in the little walled residence still known popularly as Le Hameau. Yet, the very creation of such a document is in fact the 
result of multiple translations, at once cultural (French to English), personal (neighbor to neighbor), and rhetorical (elegiac and panegyrical) - I could add to this list social, since she was part of the "Cabot-Perry" clan in Boston, and this elevated status surely played some role in her gaining access to Monet's thoroughly bourgeois enclave. Even if Perry's posthumous transcription of discussions with the French master are not monstrous distortions, they are distinctly poetic transcriptions of his thoughts and her enchantment with being so near, next door for a time, to her artistic idol. No different today for us, I would argue, than it was for Lila Cabot Perry. How can we be authentic in what we culturally do when are doing it in another language? Who are we doing this for?

14 I am not prepared to answer these questions. They have only recently occurred to me, in fact, so I am still sorting them out. But in problematizing these exchanges, I am reminded of the beginning of Walter Benjamin's classic text "The Task of the Translator" which he practically begins by asking "Is a translation meant for readers who do not understand the original?" Benjamin goes on to answer his own question by advancing a theory in which he suggests that "the basic error of the translator is that he preserves the state in which his own language happens to be instead of allowing his language to be powerfully affected by the foreign tongue." In terms of the art that a generation (or more) of American painters produced in Giverny from 1885-1915, there can be little doubt of the aptness of this remark. The best artists were those, for example, Theodore Robinson, who allowed their work to be powerfully affected by the newly obtained grammar and vocabulary that they encountered in France. Those who didn't succeed, like poor translators, preserved on canvas only their awkward American-nesses despite the available lessons around them. These are American images, of course, and they are not uninteresting in their own right, but they don't look so great on the walls of museums.

Permit me to indulge in the fantasy of using my own experience as a practical example. I moved to Normandy, from California, less than two years ago. I brought with me about six years of teaching American art history in U.S. universities, a variety of museum experiences (including directing a small university art gallery), an utterly useless (because almost wholly forgotten) knowledge French from my undergraduate and graduate school days, some treasured touristic experiences from my young adulthood, and a kind of boyish enthusiasm for the project of a "start-up" museum. (I hope I still possess the latter.) These "tools" did not prepare me well for what I encountered. I recall vividly one of the first meetings I held with the staff of the museum (90\% of whom are French natives), in which I asked everyone to bear with the changes I would no doubt initiate in the coming months. Naïve though I was, I still remarked to myself the shock registered on each and every face. In the world of American museum directors, change is a given. In rural France, I don't need to tell this audience, resistance to change can be a recreational sport. Even a museum as young as seven years old has its traditions that must be respected, for its French, and the image brought from abroad that talks immediately about changing those behaviors is fundamentally suspicious. I fear being misunderstood on this point. First of all, one of the reasons I accepted the job in the first place was my conviction that working with this particular group of people-young, eccentric in their own ways-would be a great pleasure. To be sure, no one on the staff disagreed openly with my idea that things would change under a new directorship, they simply disliked the fact that I blurted it out as a fait accompli, rather than through the course of many discussions. Over the 
intervening months, I assure you, I've learned what is often easier accomplished only after heated and circular debate is sometimes preferable to what can be done through imperial edict. The latter managerial style may be efficient and very American, but in France, it can be painfully slow and open to gross misinterpretation.

I want to move now to some very abrupt and very tentative conclusions. I have just suggested, too quickly, three broad points. First, I have claimed a special place for Giverny as an outpost, a colony, a tourist destination, and finally a center for valuable cultural exchange. These are layered identities and like palimpsests they cannot be fully ignored or dismissed. They remain to be explained. None of them are more real than the others, although some may be more consequential than others at any one specific time. We should try to bring them all into our accounts of cultural exchange. Second, I have argued that within this layered, yet perhaps hierarchical context, the Musée d'Art Américain must appear eccentric, and that we should value that eccentricity as an advantage-because it provides us with a different perspective on the center. The same is true of this conference and its placement here in Provence: I, for one, am convinced we would have a different kind of exchange (not at all to say better) in Paris. Third, I have confessed my fear that we may often be misunderstood in what we do. Cultural exchanges of any value carry risks, I would insist, and we cannot shy away from what we do for fear of that misinterpretation. Some of you in this audience may understand what I am saying from the perspective of being foreign scholars working in France. Certainly the success you have enjoyed in your endeavors gives me the greatest courage for what my work here.

In the future, I hope the Musée d'Art Américain à Giverny will develop research programs of the level, if not exactly the same kind, that those of you at this conference represent for us today. At bottom, I feel privileged to work for an institution that has the resources, space, and (hopefully, too) the will to accomplish important things. I am already influenced by the success of the American Institute at the Universite de Provence-a proof that I am maybe not so eccentric after all-and it makes great sense to me that these efforts should be complementary and in an exchange with one another. What could be better than situations, such as this one, where scholars go from city to country, shifting between languages, and geographical areas of concern to develop richer senses of the possibilities for translated experience and exchange. The work these individuals produce is to my mind stunningly significant. Scholars working in guarded and disciplinary isolation have been the norm for centuries, as have been artists working apart from the economic and academic worlds. It is exciting to behold situations where these figures might come together for valuable, even poetic exchange. Perhaps this is also possible in Giverny. 


\section{NOTES}

1. This paper is the text of a plenary lecture given at the French American Studies Association Conference in Aix-en-Provence, May 26, 2000, whose theme was "America As Image."

\section{RÉSUMÉS}

Ce texte est celui d'une des conférences d'ouverture du congrès de l'Association française d'études américaines à Aix-en-Provence, le 26 mai 2000, dont le thème était "L'Amérique Image ». Derrick R. Cartwright, qui était à l'époque du congrès directeur du Musée d'art américain à Giverny (MAAG), s'interroge sur le rôle d'un musée d'art américain en France et sur les effets de cette situation paradoxale sur notre compréhension des relations interculturelles. L'auteur a souhaité laisser à la communication son caractère oral, qui explique l'absence de notes.

\section{AUTEUR}

\section{DERRICK CARTWRIGHT}

Derrick R. Cartwright est aujourd'hui directeur du Hood Museum of Art à l'Université de Dartmouth (Dartmouth College à Hanover, New Hamphsire). Ce musée dont les origines remontent à 1772, possède l'une des plus anciennes collections des Etats-Unis. Derrick Cartwright a aussi enseigné l'art américain et la muséologie à l'Université de San Diego, à l'Université de Californie à Berkeley et dans le programme parisien de l'Université Colombia. Il est l'auteur de nombreux articles et catalogues d'exposition sur la peinture, la photographie et la théorie critique américaines des XIXe et XXe siècles. 